\title{
SPATIO-TEMPORAL ANALYSIS OF URBAN SPRAWL AND LAND USE / LAND COVER CHANGES IN A SUBURB OF LAGOS AND OGUN METROPOLISES, NIGERIA (1986-2014)
}

\author{
Adedeji, O. H.*, Adeofun, C. O., Tope-Ajayi, O. O., Ogunkola, M. O. \\ Department of Environmental Management and Toxicology \\ Federal University of Agriculture, PMB 2240, Abeokuta, Nigeria \\ *Corresponding author's Email: adedejioh@funaab.edu.ng \\ (Received: 18th November, 2019; Accepted: 25th January, 2020)
}

\section{ABSTRACT}

\begin{abstract}
Urban sprawl and land use / land cover changes in a suburb of Lagos, Nigeria were assessed using Landsat TM 1984 and 2000 and Landsat OLI of 2014. Five broad land use and land cover classes i.e. built-up area, bare ground, water body, thick forest and light forest were identified and mapped. Thick forest had the largest coverage of 8537.72 hectares $(67.52 \%)$ of the land cover while built-up was just 1075.99 hectares $(8.51 \%)$. Between 1984 and 2014 built up areas gained 6423.38 hectares (59.31\% increase) compared to 8612.09 hectares loss by thick forest cover. A post-classification change analysis from 1984 to 2014 reveals that thick and light forest types had the highest net losses because of conversion to other uses, especially built-up. Urbanization and subsequent urban sprawl is a major factor of land degradation leading to rapid losses of non-urban land uses, especially in the urban fringes.
\end{abstract}

Keywords: Land use/land cover change; change detection; remote sensing; GIS; urbanisation

\section{INTRODUCTION}

Urbanization and rapid population growth have been unprecedented in many cities of developing countries including Lagos metropolis in Nigeria. Over the past four decades, the city had witnessed rapid expansion in size and population within the traditional core areas and encroachment of agricultural lands in the fringes or suburbs. The spread out or sprawl is a dispersed development along highways, or around the city in the countryside (Bugliarello, 2003; Sudhira et al., 2004). Urban sprawl is an unplanned outgrowth of urban centres due to rapid population growth, economic development and infrastructural development initiatives (Tian et al., 2005; Stanley, 2009; Kumar and Tripathi, 2014). According to the World Bank (2015), such development creates challenges for metropolitan coordination in the delivery of basic services and the provision of infrastructure. Furthermore, urban sprawls are seen as symptomatic of the failure to adequately address congestion constraints that arise from the pressure of urban population growth (World Bank, 2015). Development of sprawls is now more rapid in developing countries and is a major contributor to the increasing land use changes and conflicts especially in the developing regions of the world (Belal and Moghanm, 2011; Csatári et al., 2013; Kumar and Tripathi, 2014) with the conversion of agricultural land into other uses (Fabiyi, 2006; Siciliano, 2013). Changes in the land use pattern because of the sprawl often have negative effects on the natural environment and sustainable urbanization (Tang et al., 2005; Ifatimehin and Ufuah, 2006, McGranahan and Tacoli, 2006; Shalaby and Tateishi, 2007; Marsh, 2013; Calò et al., 2015). Studies have shown that rapid urbanization and urban sprawl contribute to environmental problems such as deforestation, climate change, increase in the volume and rate of surface runoff, a decrease in ground water recharge and base flow, flooding, and modification of the water balance (Fohrer et al., 2001; Rosa et al., 2004; Tu et al., 2007; Rahman et al., 2014).

In view of the fact that ecosystems in urban areas are strongly influenced by anthropogenic activities, considerably more attention is currently being directed towards monitoring urban land use changes (Stow and Chen, 2002; Zang et al. 2011). Accurate and up-to-date land cover change 
information is necessary to monitor and understand both human causes and environmental consequences of such changes (Kemper et al., 2001; Cheng and Masser, 2003; Lu et al., 2004; Shalaby and Gad, 2010; Olawole et al., 2011). Presently, remote sensing and geographic information systems (GIS) provide some of the most accurate means of measuring the extent and pattern of changes in landscape conditions over time (Defries and Belward, 2000; Coppin et al. 2004; Olawole et al., 2011). Remote sensing and geographical information systems (GIS) are now widely used in the determination of past and present LU/LC to understand city patterns, detect changes, and monitor or model processes (Bhatta, 2010; Tewolde and Cabral, 2011; Iqbal and Khan, 2014; Butt et al., 2015).

Advancement in remote sensing and GIS techniques now provide options for urban sprawl to be effectively mapped and monitored (Sudhira et al., 2004; Bhatta et al., 2010; Weng, 2010; Tiwari et al., 2012). Mapping urban sprawl helps to identify areas where environmental and natural resources are critically threatened and to suggest likely future directions and patterns of growth (Xiao et al., 2006; Simmons, 2007; Tan et al., 2010; Kumar and Tripathi, 2014). GIS-based measurement tools are based on the assumption that urban sprawl is a multidimensional phenomenon which can only be measured with a multiple-indicator approach (Banai and DePriest, 2014). Until recently, the majority of studies of urban and suburban sprawl have predominantly come from the developed countries of world with relatively fewer studies from developing countries like Nigeria (Mahesh et al., 2008; Masoumi and Roque, 2015).Lagos is an emerging megacity with increasing pressures on land many of the fringe communities are having their land either legally expropriated by the government or forcefully taken over by local land speculators called Omo Onile. The city has continued to sprawl and encroach in all directions into lands in surrounding towns and villages creating land use problems. This study attempts to examine the changes in land use changes and pattern of Isheri, Magboro and its environs in northeastern part of Lagos metropolis using satellite remote sensing data and GIS. The study employed common methods such as maximum likelihood classification and change detection (Jensen, 2000; Skidmore, 2002; Hagner and Reese, 2007). The objectives of the study are to 1) access the trends and patterns of urban sprawl in the study area between 1984 - 2014, 2) monitor urban land use land cover change between 2000-2014, and 3) predict future land use / land cover scenarios for the next 30 years (until 2044).

\section{MATERIALS AND METHODS Study area}

The study area includes Isheri, Magboro and Environs and lies between $6^{\circ} 37^{\prime}$ to $6^{\circ} 44^{\prime}$ North latitude and $3^{\circ} 21^{\prime}$ to $3^{\circ} 27^{\prime}$ East longitude (Figure 1). The area falls within Ogun State, with closely proximity to Lagos Metropolis the industrial capital of Nigeria and the nation's seaport. According to Koppen-Geiger climate classification, this climate is classified as Aw (Pidwirny, 2011). There is difference of $328 \mathrm{~mm}$ of precipitation between the driest and wettest months. During the year, the average temperature varies from $25.1^{\circ} \mathrm{C}$ to $33.2^{\circ} \mathrm{C}$. Precipitation here averages $1608 \mathrm{~mm}$. The driest month is December, with $17 \mathrm{~mm}$ of rain. With an average of $34 \mathrm{~mm}$, the most precipitation falls in June. There are two distinct seasons in the area, namely the rainy season, which lasts from March/April to October/November, and the dry season, which lasts for the rest of the year, October/November until March/April. The temperature is relatively high during the dry season $\left(31.4^{\circ} \mathrm{C}\right.$ to $\left.33.2^{\circ} \mathrm{C}\right)$. The harmattan, which brings in the northeastern winds from December to February, has an ameliorating effect on the dry season high temperatures $\left(31.8^{\circ} \mathrm{C}-33.2^{\circ} \mathrm{C}\right)$ Low temperatures are experienced during the rains, especially in July and August when the temperature could be as low as $25^{\circ} \mathrm{C}$. A social survey of the area was carried out by physical familiarization with the area. The area is partly muddy, loamy and sandy, and the vegetation is light with thick forest while the topography is partly undulating and relatively flat terrain

\section{Data source}

The data collection involved the acquisition of satellite imageries of the study area. Landsat images were the primary data type used for the 
comprehensive classification of the study area. Landsat satellite imageries for 1984, 2000 and 2014 were freely downloaded from the official website of Global Land Cover Facility (GLCF) (bttp://wrw:glcf.umiacs.umd.edu). The GLCF is hosted by the University of Maryland, USA. The Global Land Cover Facility (GLCF) provides earth science data and products to help everyone to better understand global environment systems. Landsat TM images were used because of their relatively high spatial resolution $(30 \mathrm{~m})$ and their wide application for land cover classification across the world (Lillesand and Kiefer 2000,
Masek et al. 2006). Landsat images were selected from among the various levels of spatial, spectral, radiometric and temporal resolution satellite images because of their long-term availability (Miller et al. 2011), cost-effectiveness and timeliness (Weng 2012). Table 1 shows the properties of the Landsat images used. The irregular intervals came about because of unavailability of cloud-free images in some of the years. The three scenes corresponded to path 191 and row 055 of the WRS-2 (Worldwide Reference System).

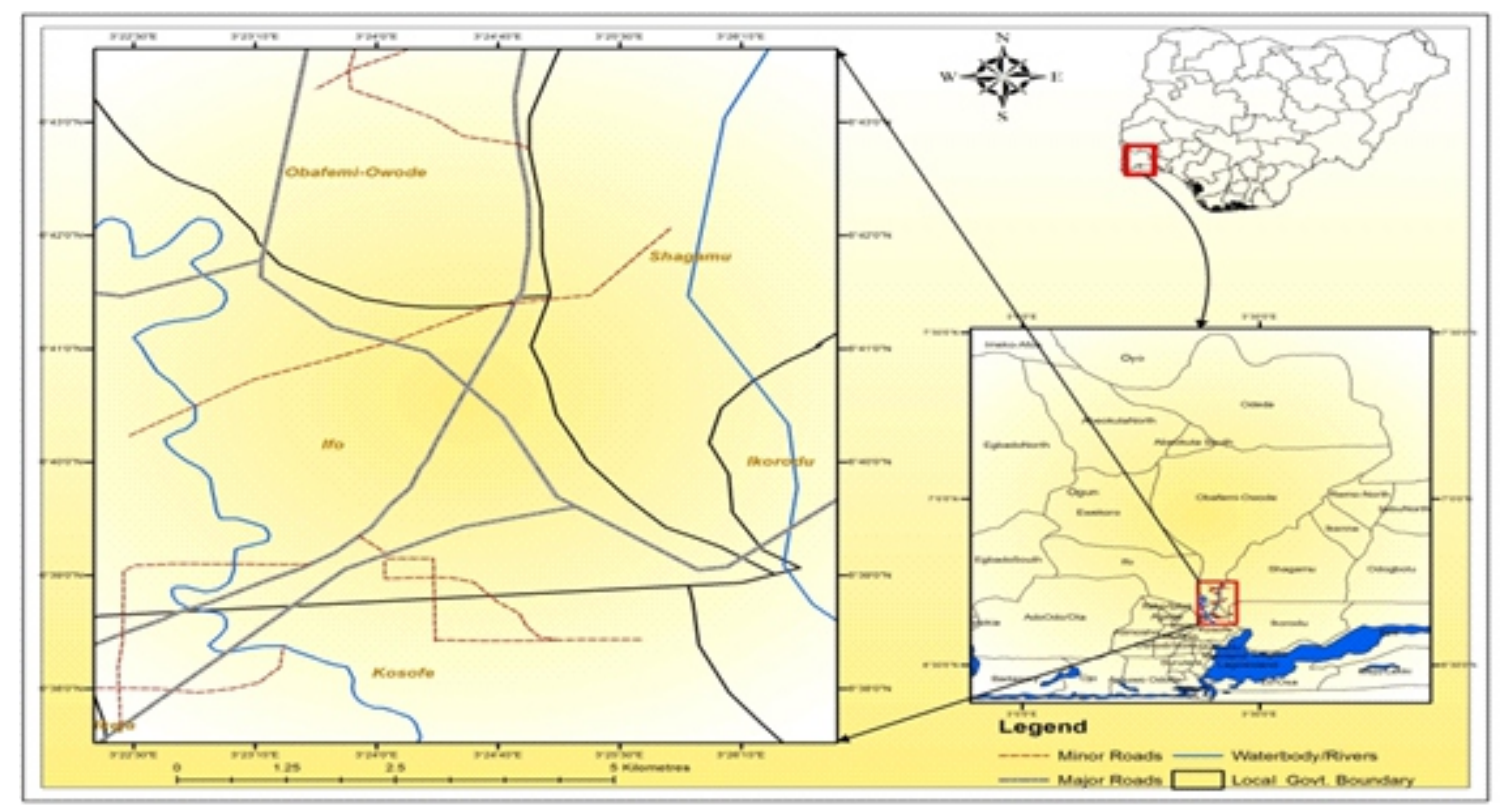

Figure 1: Geographical location of the study area

Ground truth information was combined with the classified images to assess the accuracy of image classification. Field survey was carried out to get first-hand information about the study area. Landsat TM (Thematic Mappers) and OLI/TIRS
(Operational Land Imager/Thermal Infrared Sensor) for 1984, 2000 and 2014 were used for classifying the study area into built-up, bare ground, water-body, thick forest and light forest.

Table 1: The properties of the Landsat images used

\begin{tabular}{lllccl}
\hline Sensor & Year & $\begin{array}{l}\text { Spatial } \\
\text { Resolution(m) }\end{array}$ & Path & Row & $\begin{array}{l}\text { Acquisition } \\
\text { Date }\end{array}$ \\
\hline Landsat TM & 1984 & $30 \mathrm{~m}$ & 191 & 055 & $1984 / 04 / 18$ \\
Landsat TM & 2000 & $30 \mathrm{~m}$ & 191 & 055 & $2000 / 02 / 06$ \\
Landsat & 2014 & $30 \mathrm{~m}$ & 191 & 055 & $2014 / 12 / 07$ \\
OLI/TIRS & & & & \\
\hline
\end{tabular}




\section{Image Processing}

The study area was extracted from Landsat TM for 1984, 2000 and OLI/TIRS for 2014 respectively by clipping the vector map of the study area to the Landsat images; band four, three and two for Landsat TM and band five, four and three for Landsat OLI/TIRS were stacked and clipped to the study area vector map shapefile for further processing in Idrisi Selva where histogram equalization was carried on the stacked or composite images to make them clearer. Effective image processing is critical to successful urban land use land cover mapping and change detection (Mussie, 2011). The False Colour Composite (FCC) of the Red, Blue and Green (RGB) bands for all the three periods of the study was used to create classified images for land use change detection in measuring urban sprawl with GIS. On the false colour composite (FCC) images developed (Figure 2), water bodies appeared dark blue to black as they absorb all the wavelengths, bare ground appeared as green, vegetation showed up in red, and settlements/built-up areas and roads showed up in shades of cyan (Eastman 2009). Figure 2 shows the FCC $(\mathrm{RGB}=$ bands 4,3 and 2 (Landsat TM) and bands 5, 4 and 3 (Landsat OLI/TIRS) image of the study area for different time periods.

\section{Pre-processing of satellite images and classification}

Pre-processing of the satellite images allowed an accurate classification at non-coincident dates and this included geometric, atmospheric and topographic corrections to ensure spatial and temporal comparability of the datasets (Melendez-Pasto 2014). The Landsat data acquired for this study were coregistered to a common UTM projection. The 2014 Landsat OLI image was first geo-referenced using 1/50,000scale topographic map of the study area and then, the images from 1984 and 2000 were image-toimage registered using the 2014 image. The root mean square error (RMSE) was carefully kept below 0.5 pixels.
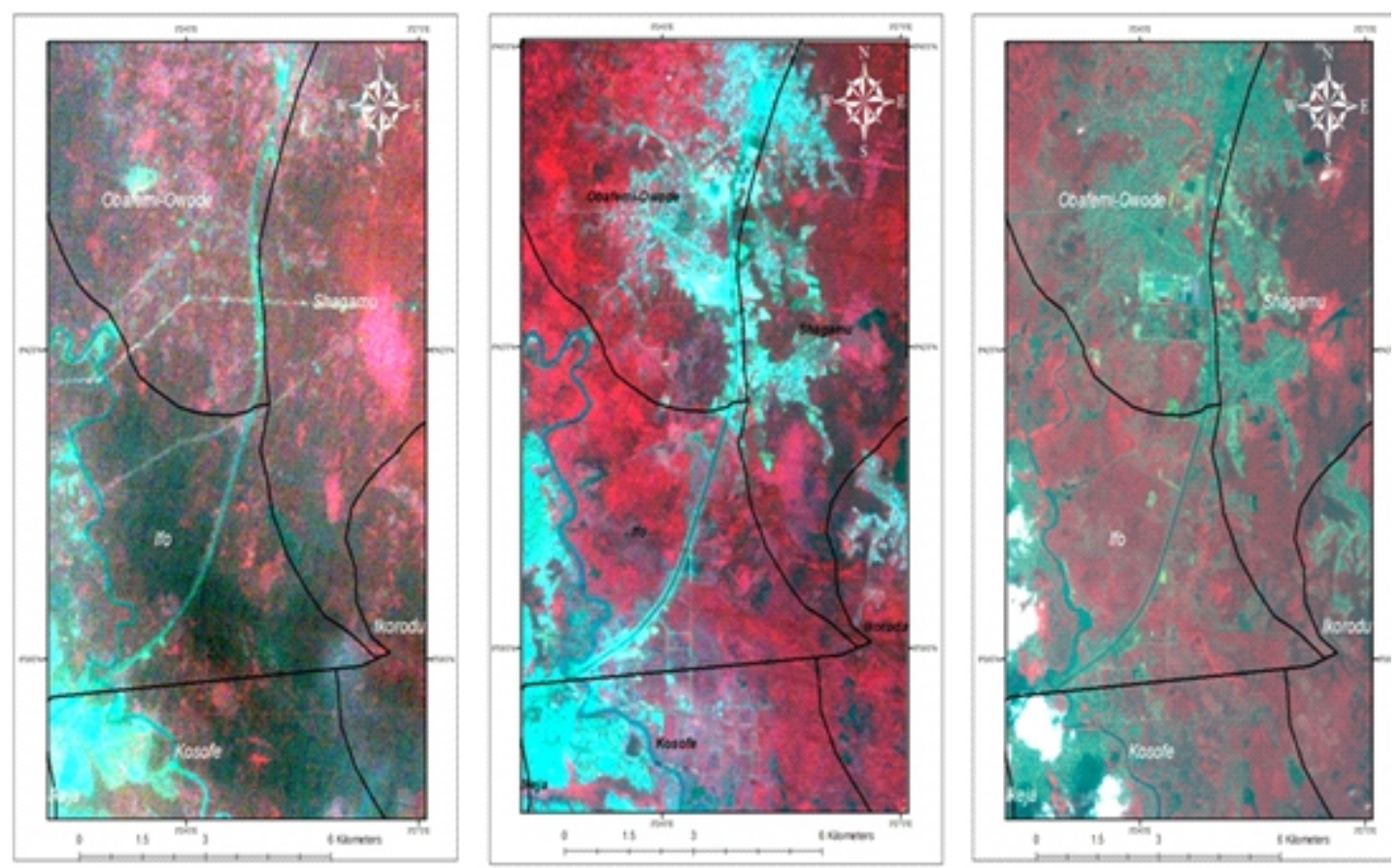

Figure 2: False colour composite (FCC) of Landsat imageries for 1994, 2000 and 2014

The images were classified within the GIS environment using the supervised classification method, which classified features of interest on the Landsat TM for 1984 and 2000, and Landsat OLI/TIRS for 2014, respectively into built-up area, bare ground, water body, thick forest and light forest using the maximum likelihood algorithm. Maximum Likelihood classification assumes that the statistics for each class in each band are normally distributed. This calculates the probability that a given pixel belongs to a specific 
class (Tempfli et al. 2002). A supervised method was utilized simply because it permits selection of pixels that represent pattern or land use features that is recognizable or identifiable with the use of other source such as ground truth data (Iqbal and Khan 2014).

This involves the training of computer to recognize patterns in the remotely sensed image by sorting pixels into finite number of individual classes, or categories of data, based on their data file values. The accuracy of the supervised classification depends on the sampling and the quality of the training data, which is more suitable than the unsupervised method (Yiran et al. 2012, Iqbal and Khan 2014). Training is the process of defining the criteria by which these patterns are recognized (Mussie 2011). Samples that have known identity are located within training areas. Training areas are said to be regions on the image that can be clearly matched to areas of known identity on the ground; it is therefore used to typify the spectral properties of the on-ground areas they represent (Meyer and Turner 1994). Each pixel in the image was therefore compared to these signatures and labelled as the class it most closely resembles digitally. This was done with Idrisi Selva software. An Anderson et al. (2001) level 1 classification scheme was adopted for the study area and five land use classes were used for the classification i.e. built-up, bare ground, water-body, thick forest and light forest (Table 2).

Table 2: Land Classification

\begin{tabular}{|l|l|}
\hline Land use/Land cover categories & Description \\
\hline Built-up & $\begin{array}{l}\text { Areas that have been populated with } \\
\text { permanent residents or cover with built up } \\
\text { surface }\end{array}$ \\
\hline Bare ground & Area covered with bare surface \\
\hline Water bodies & $\begin{array}{l}\text { Areas covered with water such as rivers, } \\
\text { reservoirs and swamps }\end{array}$ \\
\hline Thick forest & Areas covered with tall tree \\
\hline Light forest & $\begin{array}{l}\text { Areas covered with shrubs and herbaceous } \\
\text { vegetation. }\end{array}$ \\
\hline
\end{tabular}

Source: Adapted from level 1 classification by Anderson et al. (2001)

\section{Change Detection}

One of the prerequisites for understanding environmental changes is a successful land change detection modeller (LCM). For this study, change detection analysis was carried out on Landsat images of different years (i.e. 1984, 2000 and 2014) to analyse the pattern and trend of change in the study area. The built-up, bare ground, waterbody, thick forest and light forest of the three different years were used and compared from the classified images so that the dynamic changes and the characteristics of environmental changes could be recognized.

\section{Land Change Modeller (LCM)}

Among several available land use modelling tools and techniques, some of the most commonly used models are embedded in IDRISI, such as, Land
Change Modeller, Markov Chain, CA Markov, GEOMOD and STCHOICE (Lu et al. 2004). In this study, Land Change Modeller (LCM), Markov and CA Markov were used to understand the changes that have occurred in the land use overtime. Change Analysis and Map Transition Option in LCM is a mapping tool to visualize the change that occurred from all the other land classes to the built-up, bare ground, water-body, thick forest and light forest class, and for predicting the course of change into the future (Fabio 2007). Modelling using LCM requires mainly two time categorical maps. The classified maps of 2000 (time-1) and 2014 (time-2) were used as inputs for the Change Analysis Tab of IDRISI, which enabled the analysts to understand the gains and losses and the transition of areas among the land use and land cover classes; and to 
quantify the changes that occurred from time- 1 to time-2. Results of the quantified and analysed data are then presented in a chart and/or map outputs.

In LULC modelling, the process determines the $t 1$ to $t 2$ LULC distribution using a transition matrix. This can be expressed as:

$v t_{2}=M \times v t_{1}$

where:

$\mathrm{vt} 1$ is the LULC proportion vector input; $\mathrm{vt} 2$ is the LULC proportional vector output; $\mathrm{M}$ is the mxm transition matrix for the time difference $\Delta t=t_{2}-t_{1}$.

The transition probabilities file is a matrix that records the probability that each land cover category will change to every other category.

\section{Markovchain model}

A Markovian process is one in which the state of a system at time two can be predicted by the state of the system at time one given a matrix of transition probability from each other class to every other cover class (Borak et al. 2000). The quality of predicted changes depends on the accuracy of the analysis of the past and present conditions, the data quality and the model used for the predictions (Mozumder and Tripathi 2014). The Markov module was used to create a transition probability matrix. As input, it takes two land cover maps to produce the following outputs: a transition probability matrix and transition area matrix.

\section{Cellularautomata (CA Markov)}

CA Markov takes as input the name of the land cover map from which change should be projected, the transition area file produced by Markov from analysis of that image and an earlier one, and a collection of suitability images that express the suitability of a pixel for each of the land cover types under consideration (Borak et al. 2000). It then begins an iterative process of reallocation of land cover until it meets the area total predicted by Markov module.

\section{RESULTS AND DISCUSSION}

The study area was classified into different land uses; namely, built-up, bare ground, water-body, thick forest and light forest. Figure 3 shows the classified images of the study area for the study periods: 1984, 2000 and 2014. Analysis of land use/land cover (LU/LC) in the study area shows in 1984, thick forest had the largest coverage of 8537.72 hectares $(67.52 \%)$ of the land cover followed by the light forest area with $18.68 \%$ (Table 3). The built-up area constituted only $8.51 \%$ while, bare ground covered $3.65 \%$ and water body was $1.64 \%$. However compared with 1984, thick forest recorded a decrease in its coverage constituting only 2997.52 hectares (23.7 $\%$ ) of the total area by the year 2000 . The result showed rapid land use changes in the study area with the built-up area having the largest percentage $(42.94 \%)$ of land cover followed by light forest $(31.35 \%)$. In the same period, water bodies constituted about $0.90 \%$ of the land cover, while the bare ground decreased to $1.10 \%$. Furthermore, by the year 2014, the built-up had increased to $59.31 \%$ while the light forest also increased to $38.80 \%$. Comparatively, thick forest further declined to $0.59 \%$ and bare ground to $0.13 \%$ (Table 3 ).

Overall, the amount of built-up area increased at a very fast pace in contrast to the rapid decline of thick forest. The reduction in thick forest can be attributed to spill over of urbanization and population from the Lagos metropolis. These two in turn continually require more land, which results in land occupied by built-up areas. The growth in the population of dwellers who live or work in neighbouring city i.e. (Lagos,) around the study area is rapidly increasing which in turn constantly increases the demand for land to use in urban and industrial expansion. 


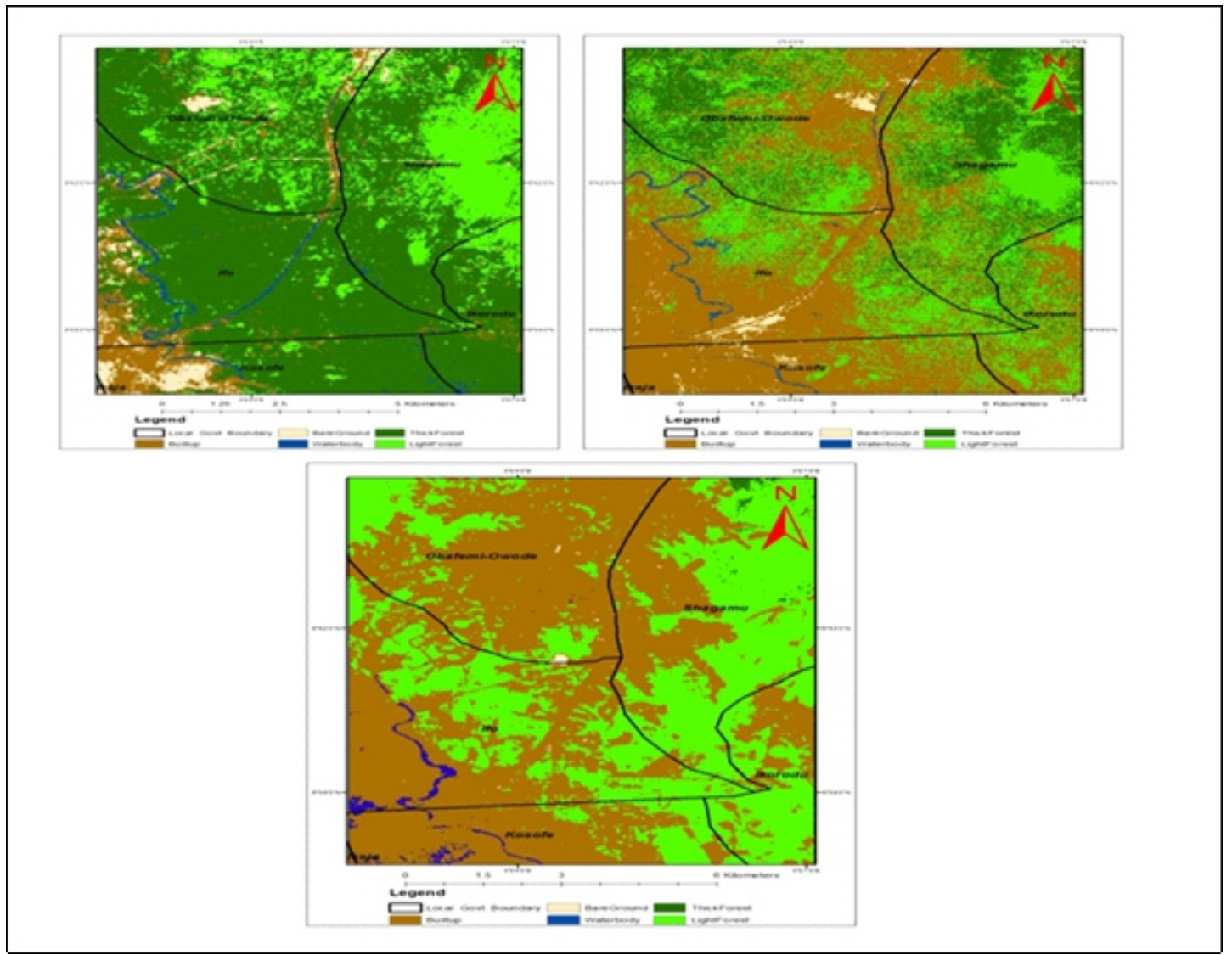

Figure 3: Classified images of the study area for 1984, 2000, and 2014

Land use change, however does not come without a cost. Anthropogenic activities such as deforestation, sand mining and dredging are some basic activities, which cause degradation in the study area. A consequence of these changes is not only impacting on humans but also on other living species (e.g. vegetation). Dwelling houses, schools, religious camps and companies are springing up in the study area. Most of these developments are happening with little or no planning at all, which is resulting in haphazard urban development. The rapid population growth is one of the major factors that are responsible for the spatial growth and the associated pressure on different land use types leading to conversion of one land use class to another.

Table 3: Size and proportion of land cover classes from year 1984-2014

\begin{tabular}{lllllll}
\hline \multirow{2}{*}{$\begin{array}{l}\text { Land cover } \\
\text { types }\end{array}$} & \multicolumn{2}{l}{ Area in 1984 } & \multicolumn{2}{c}{ Area in 2000 } & \multicolumn{2}{l}{ Area in 2014 } \\
\cline { 2 - 7 } & Hectares & $\%$ & Hectares & \% & Hectares & \% \\
\hline Built-up & 1075.99 & 8.51 & 5429.53 & 42.94 & 7499.37 & 59.31 \\
Bare ground & 460.71 & 3.65 & 139.38 & 1.10 & 16.47 & 0.13 \\
Water body & 207.61 & 1.64 & 114.04 & 0.90 & 148.05 & 1.17 \\
Thick forest & 8537.72 & 67.52 & 2997.52 & 23.71 & 74.37 & 0.59 \\
Light forest & 2362.10 & 18.68 & 3963.67 & 31.35 & 4905.90 & 38.80 \\
Total & 12644.130 & 100 & 12644.130 & 100 & 12644.130 & 100 \\
\hline
\end{tabular}

Comparing the classified images of year 1984, 2000 and 2014, the under listed can be noticed.

- A progressive increase in land use change in respect of built up area. In year 1984, the classified image showed that a total of 1075.99 hectares was developed. In year 2000 , a total of 5429.53 hectares was 
developed and in year 2014, a total of 7499.37 hectares was developed.

- A rapid decrease in thick forest. In 1984, the classified image showed that a total of 8537.72 hectares was covered by thick forest. In year 2000 , it reduced to a total of 2997.52 hectares and in year 2014, it declined to 74.34 hectares.

- An increase in the hectares covered by light forest. In year 1984, a total of 2362.10 hectares was covered by light forest. In year 2000, a total of 3963.67 hectares and in year 2014, a total of

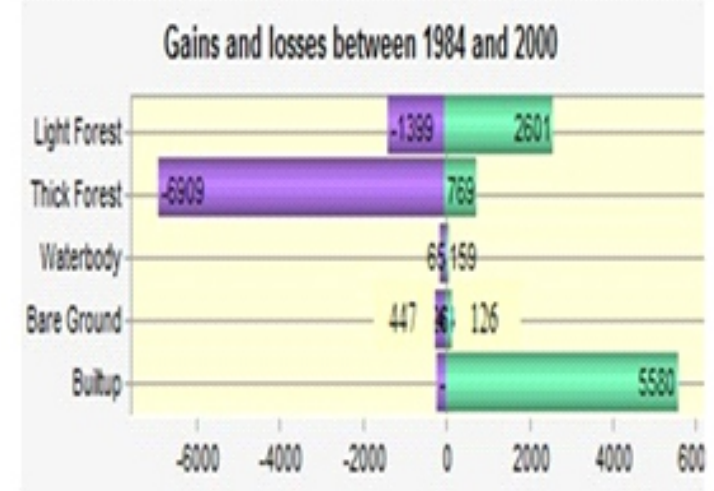

4705.90 hectares.

\section{Land Change Modeller (LCM) \\ Gain and Losses}

Gains and losses in different land uses between 1984 and 2000 are shown in Figure 4. For the builtup, about 226 hectares was lost and 5580 hectares was gained, while a 1399 hectare lost and a 2601 hectare gain were observed for light forest. Furthermore, a 6909 hectare loss and a 769 hectare gain were observed for thick forest between 1984 and 2000 .

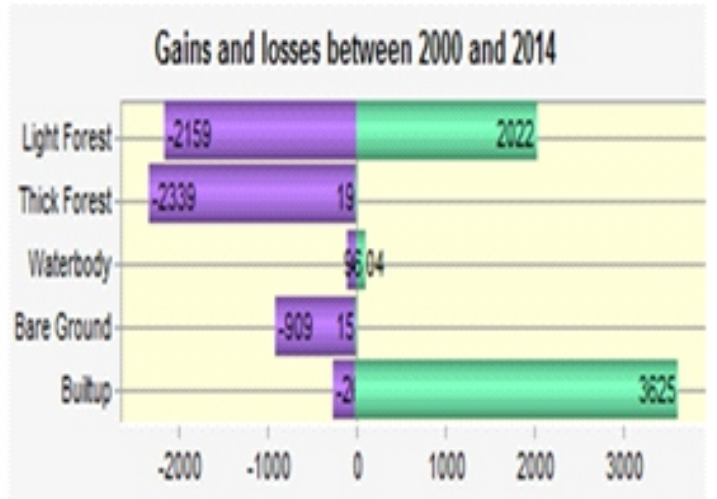

Figure 4: Gain and losses of different land uses between 1984 - 2000 and 2000-2014

Gains and losses in different land uses between 2000 and 2014 showed that about 15.23 hectares was lost by built-up area while 3625 hectares was gained. Simultaneously during the same period, a 2159 hectare loss and 2022 hectare gain were observed for light forest. In addition, a 2339 hectare loss and 19 hectare gain were observed for thick forest during the period.

\section{Net Changes}

In the period between 1984 and 2000, the built-up

area had an increase of 5354 hectares and bare ground deceased by 321 hectares, while thick forest and light forest decreased by 6140 hectares and 1202 hectares, respectively (Figure 5). The net change in area covered by different land uses between 2000 and 2014 showed that the built-up area increased further by 3359 hectares, while thick forest and light forest decreased further by 2320 hectares and 137 hectares, respectively.

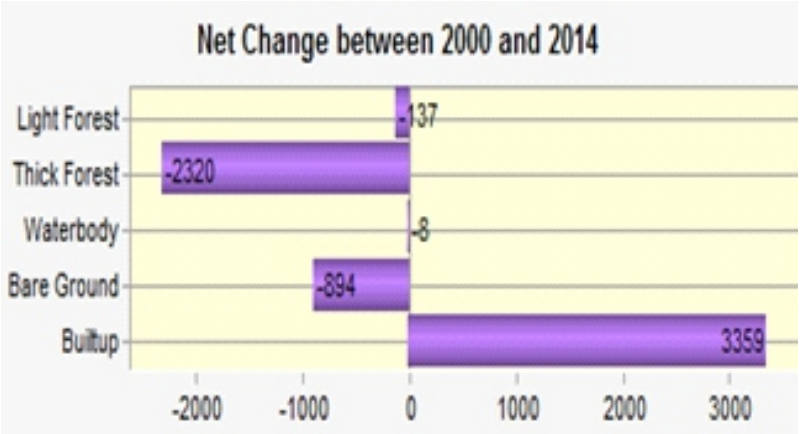

Figure 5: Net changes of different land uses between 1984 and 2000 


\section{Change detection}

Cross-tabulation analysis (Eastman 2012a, b) was applied to determine the LU/LC changes over 1984-2000 and 2000-2014. The analysis allows for the determination of areas that changed from one class to another at specific periods spatially and quantitatively (Ozturk 2015). Figures 6 and 7 depict the transition maps indicating changes from one type of land use to the other type during the study periods.

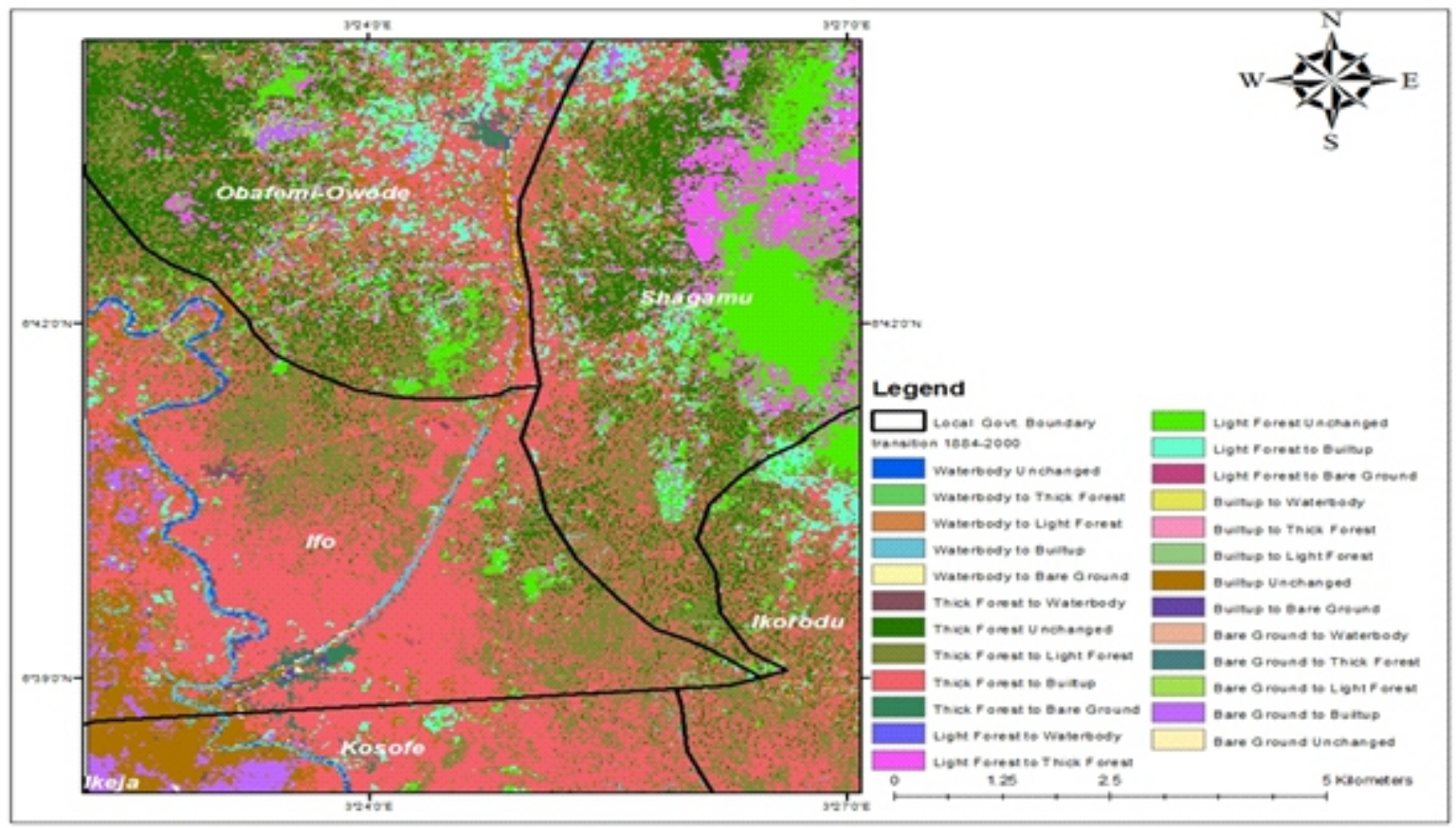

Figure 6: Change in area covered of different Land use and Land cover between 1984and 2000

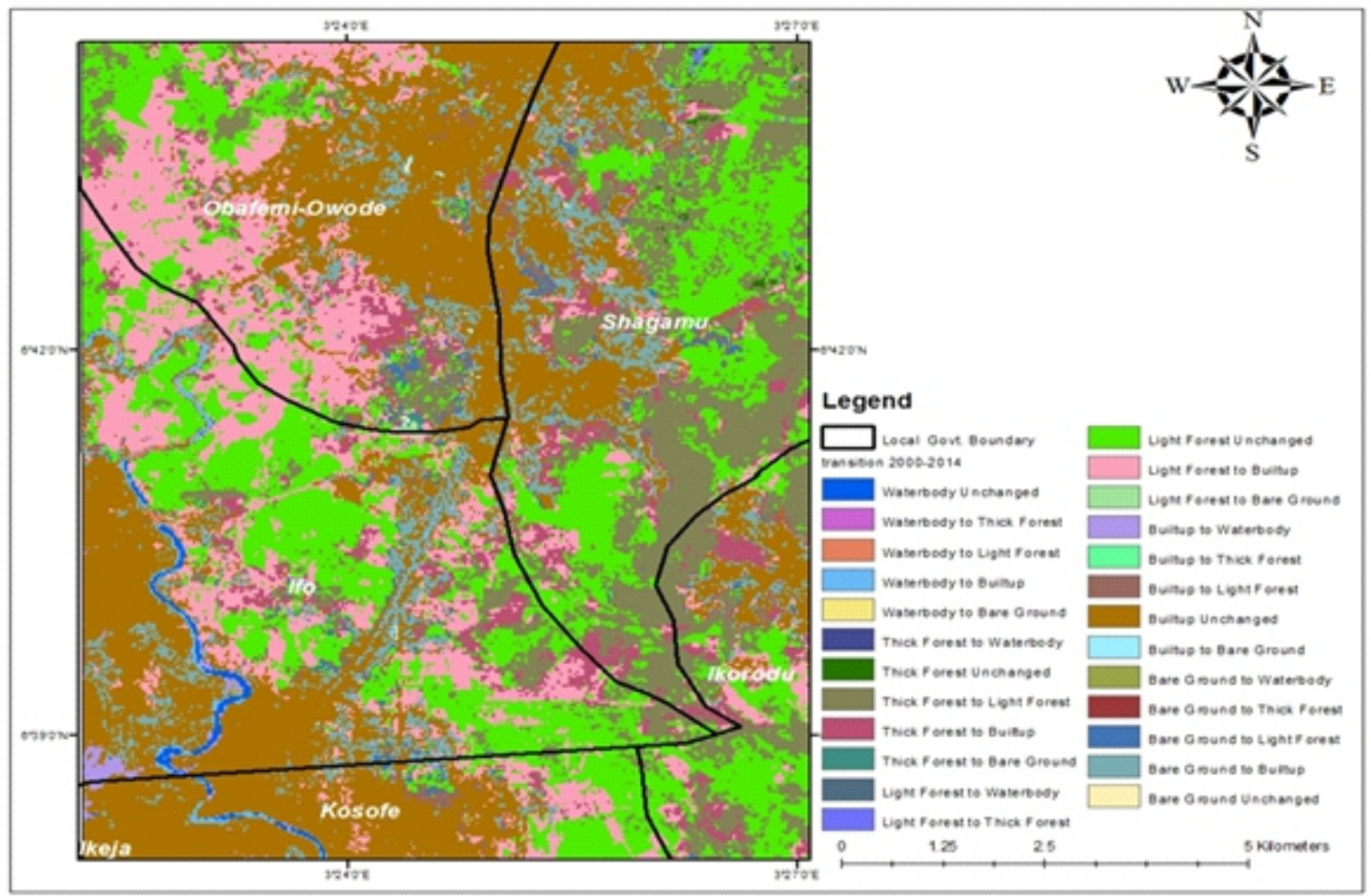

Figure 7: Change in area covered of different Land use and Land cover between 2000 and 2014 
The cross-tabulation table shows the frequencies of changed or unchanged classes (Eastman 2012a). Tables 4 and 5 show the transition matrices of land uses from 1984-2000 and 20002014, respectively. The period between 1984-2000 witnessed rapid conversion of thick and light forest to built up areas due to the demand for land by the growing population in Lagos and the establishment of the Ogun State Property Investment Corporation (OPIC) that encouraged development of housing estates in the area.

Table 4: Transition matrix of the study area from 1984 to 2000

\begin{tabular}{|c|c|c|c|c|c|c|c|}
\hline & 2000 (hectares) & & & & & & \\
\hline & $\begin{array}{l}\text { Land } \\
\text { cover types }\end{array}$ & Built-up & $\begin{array}{l}\text { Bare } \\
\text { ground }\end{array}$ & $\begin{array}{l}\text { Thick } \\
\text { forest }\end{array}$ & $\begin{array}{l}\text { Light } \\
\text { forest }\end{array}$ & $\begin{array}{l}\text { Water } \\
\text { body }\end{array}$ & $\begin{array}{l}\text { Total } \\
\text { area HA) }\end{array}$ \\
\hline (ூ) & Built-up & 849.53 & 30.70 & 67.99 & 107.70 & 20.06 & 1075.98 \\
\hline 㫕 & Bare ground & 403.20 & 13.65 & 11.70 & 30.78 & 1.38 & 460.71 \\
\hline 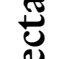 & Thick forest & 4346.43 & 78.22 & 1628.80 & 2443.09 & 41.18 & 8537.72 \\
\hline$\stackrel{\mathscr{Z}}{=}$ & Light forest & 699.27 & 12.35 & 685.38 & 962.68 & 2.44 & 2362.12 \\
\hline 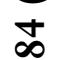 & Water body & 131.10 & 4.47 & 3.66 & 19.41 & 48.98 & 207.62 \\
\hline$\approx$ & Total area (HA) & 6429.53 & 139.39 & 2397.53 & 3563.66 & 114.04 & 12644.15 \\
\hline
\end{tabular}

Between 1984-2000, about 4346.3 hectares of thick forests were removed to pave the way for the erection of buildings and many other infrastructures including the Lagos-Ibadan Expressway

Table 5: Transition matrix of the study area from 2000 to 2014

\begin{tabular}{|c|c|c|c|c|c|c|c|}
\hline & 2014 (hectares) & & & & & & \\
\hline & $\begin{array}{l}\text { Land } \\
\text { cover types }\end{array}$ & Built up & $\begin{array}{l}\text { Bare } \\
\text { ground }\end{array}$ & $\begin{array}{l}\text { Thick } \\
\text { Forest }\end{array}$ & $\begin{array}{l}\text { Light } \\
\text { forest }\end{array}$ & $\begin{array}{l}\text { Water } \\
\text { body }\end{array}$ & $\begin{array}{l}\text { Total } \\
\text { area (HA) }\end{array}$ \\
\hline 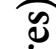 & Built-up & 3870.90 & 5.13 & 67.99 & 175.33 & 86.67 & 4206.02 \\
\hline 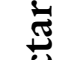 & Bare ground & 801.00 & 1.62 & 11.7 & 101.62 & 7.5 & 923.44 \\
\hline$\ddot{Z}$ & Thick forest & 598.32 & 3.96 & 56.44 & 1737.19 & 0.09 & 161.63 \\
\hline$\stackrel{0}{0}^{f}$ & Light forest & 2133.90 & 5.22 & 17.90 & 2884.87 & 2.26 & 2398 \\
\hline 8 & Water body & 92.07 & 0.54 & 3.66 & 11.89 & 53.47 & 4957.04 \\
\hline & Total area (HA) & 7495.39 & 16.47 & 157.69 & 4910.90 & 149.99 & 12644.15 \\
\hline
\end{tabular}

Determining the trend and the rate of land cover conversion are necessary for the development planner in order to establish rational land use policy (Shalaby and Gad 2000). The magnitude of the urban sprawl depicts the state of land use and urbanization process at a particular point of time (Tiwari et al. 2012). The trends and magnitudes of changes in land use / land cover in the study area were calculated and presented in Tables 6 and 7. To understand the magnitude of urban sprawl land use patterns in the study area, the Landsat imageries of 1984, 2000 and 2014 were studied. The scenario in the year 1984 depicts the study area has a vast light forest covering about sixtyeight per cent of the total area (Table 6). At that period, the area had a built-up land of merely $8.51 \%$ of the total land. Bare ground and thick forest were $3.64 \%$ and $1.64 \%$ of the total area respectively. However, by 2000 , bare ground, thick forest and light forest suffered losses in both absolute and relative terms between year 1984 and 2000. Water areas showed a decrease from $18.69 \%$ to $12.66 \%$ in absolute terms. Absolutely, $2.54 \%$ of bare ground, $0.74 \%$ of thick forest and $43.81 \%$ of light forest were lost during the period of fourteen years. 
Table 6. Land use/ land cover change: Trend and magnitude (1984 and 2000)

\begin{tabular}{lllllll}
\hline $\begin{array}{l}\text { Land cover } \\
\text { classes }\end{array}$ & Year 1984 & \multicolumn{2}{l}{ Year 2000 } & \multicolumn{2}{l}{ Year 1984-2000 changes } \\
\hline & Ha & $\%$ & Ha & $\%$ & $\begin{array}{l}\text { Absolute } \\
\text { increment (\%) }\end{array}$ & $\begin{array}{l}\text { Relative } \\
\text { increment } \\
\text { since 2000 (\%) }\end{array}$ \\
\hline Built-up & 1075.99 & 8.51 & 5429.53 & 42.94 & 34.43 & 404.58 \\
Bare ground & 460.71 & 3.64 & 139.38 & 1.10 & -2.54 & -69.78 \\
Thick forest & 207.61 & 1.64 & 114.04 & 0.90 & -0.74 & -45.12 \\
Light forest & 8537.72 & 67.52 & 2997.52 & 23.71 & -43.81 & -64.88 \\
Water body & 2362.10 & 18.69 & 3963.66 & 31.35 & 12.66 & 67.74 \\
& 12644.13 & 100 & 12644.13 & 100 & Not applicable & Not applicable \\
\hline
\end{tabular}

These losses translated into increases of the amount of built up and water body. Furthermore, bare ground and light forest suffered loss in both absolute and relative terms between year 2000 and 2014. In absolute terms, $0.97 \%$ of bare ground and $23.12 \%$ of light forest were lost during the fourteen-year period, translated into an increase in the amount of built-up areas. Built-up area increased from to $42.94 \%$ in 2000 and to $59.31 \%$ in 2014 (Table 7). The year 2000 has $0.90 \%$ of thick forest and $23.71 \%$ of light forest showing a sharp decrease in vegetal cover in the area. This depicts how the process of urban sprawl has affected the land use pattern in the study area causing rapid deforestation and environmental degradation. During the period between 2000 and 2014 , there was an absolute increase in the built-up area by $16.37 \%$ while the extent of the light forest reduced significantly.

Table 7: Land use/land covers change: Trend and magnitude 2000 and 2014

\begin{tabular}{lllllll}
\hline $\begin{array}{l}\text { Land cover } \\
\text { classes }\end{array}$ & Year 2000 & \multicolumn{3}{c}{ Year 2014 } & \multicolumn{2}{l}{ Year 2000-2014 changes } \\
\hline & Ha & $\%$ & Ha & $\%$ & $\begin{array}{l}\text { Absolute } \\
\text { Increment (\%) }\end{array}$ & $\begin{array}{l}\text { Relative } \\
\text { increment } \\
\text { since 2000 (\%) }\end{array}$ \\
\hline Built-up & 5429.53 & 42.94 & 7499.37 & 59.31 & 16.37 & 38.12 \\
Bare ground & 139.38 & 1.10 & 16.47 & 0.13 & -0.97 & -88.18 \\
Thick forest & 114.04 & 0.90 & 148.05 & 1.17 & 0.27 & 30.00 \\
Light forest & 2997.52 & 23.71 & 74.37 & 0.59 & -23.12 & -97.51 \\
Water body & 3963.66 & 31.35 & 4905.90 & 38.80 & 7.45 & 23.76 \\
Total & 12644.13 & 100 & 12644.13 & 100 & Not applicable & Not applicable \\
\hline
\end{tabular}

\section{Prediction of the future land use/land cover scenario}

The prediction of the future land use/land cover scenario by the next thirty years (2044) is shown in Figure 8. It was predicted based on the trends and magnitudes of changes presently occurring in the area. The prediction showed that bare ground and thick forest would have declined drastically to the extent that there might not be any visible bare ground and thick forest, which can be attributed to an increase in anthropogenic activities such as housing, commercial activities and farming in the study area. Water body in the study area has been fluctuating since 1984 to date and the projection is that in next 30 years it will continue to fluctuate. 


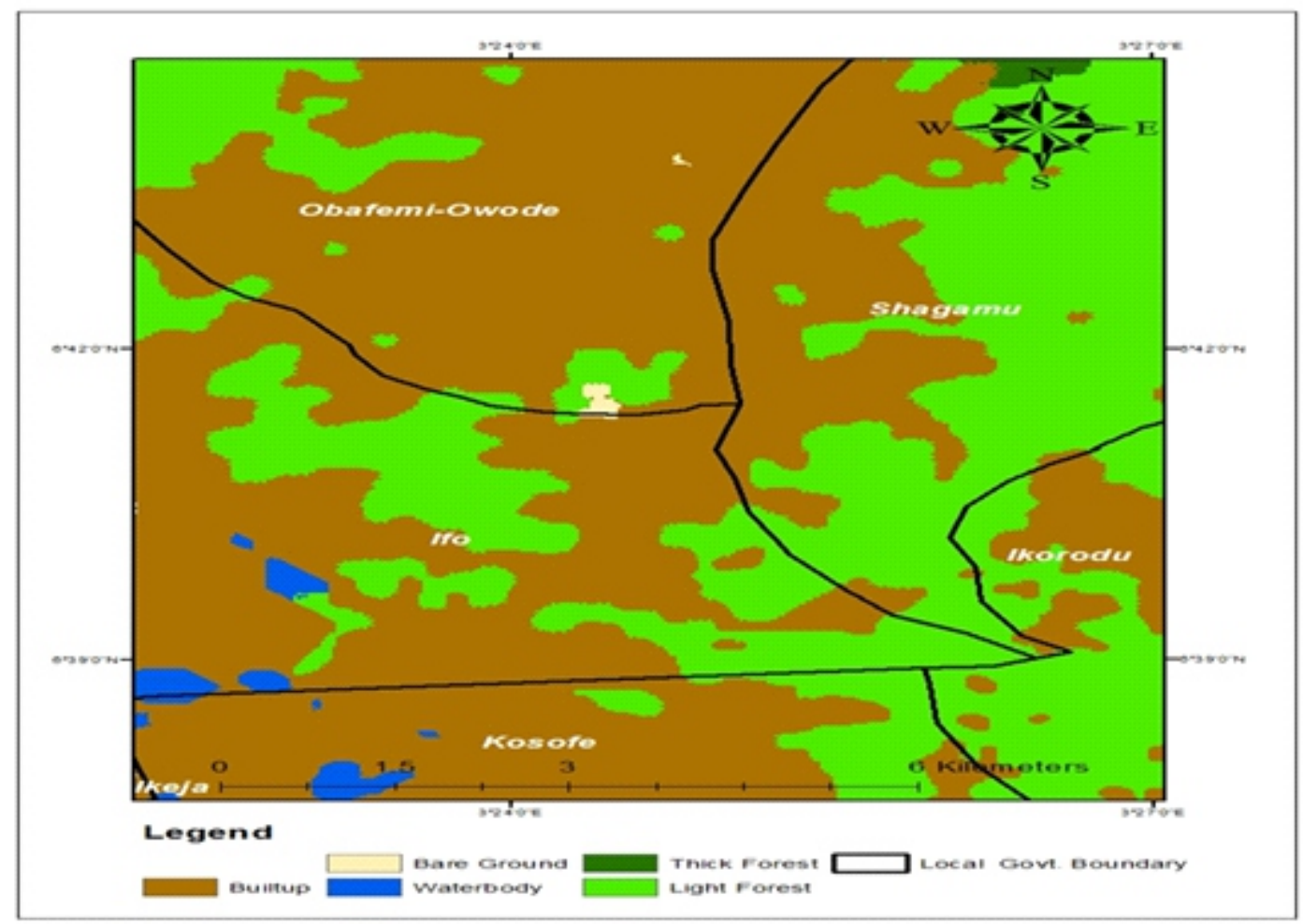

Figure 8: Projection of land uses in the study area by year 2044

Impacts of urban sprawl on the environment

In this study, we have extracted and quantified the land use/land cover change and urban sprawl in a suburb of Lagos Metropolis for 1984, 2000 and 2014 from Landsat TM (Thematic Mappers) and Landsat OLI/TIRS (Operational Land Imager/Thermal Infrared Sensor) images. Urbanization and subsequent urban sprawl is a major factor of land degradation leading to rapid losses of non-urban land uses, especially in the urban fringes. Although conversion of erstwhile forested lands into urban land uses may have some social and economic benefits, however, adverse effects on the natural environment are enormous. The effects may be local, regional and global in dimension and may include land degradation, declining water quality, loss of biodiversity, loss and fragmentation of the natural resource base and climate change (Wickham et al. 2000, Tang et al. 2005). The major impact of urban sprawl is also felt on the productive agricultural lands, surface water bodies, changing urban hydrology and creating new hydrological environment (Alberti et al. 2000, Banzhaf et al. 2009). Due to lack of prior planning, settlements developing in the sprawl areas are devoid of basic amenities like water, electricity and sanitation.
Haphazard urban development in the study area is a major threat to the health, productivity and biodiversity of both aquatic and terrestrial ecosystems. The result demonstrates that deforestation is a serious environmental problem in the study area as it causes destruction of habitats that support biodiversity, and affects the hydrological cycle and increases soil erosion and flooding (Ghebrezgabher, et al. 2016). Furthermore, the rapid conversion of farmland and thick forest to urban development reduces the amount of open space and environmental amenities for local residents.

\section{CONCLUSION}

This study demonstrated the use of remote sensing and GIS techniques for the spatiotemporal analysis of urban sprawl and land use / land cover changes in a suburb of Lagos metropolis, Nigeria. The supervised classification approach using the Maximum likelihood algorithm was employed and five broad classes of land use and land cover classes i.e. built-up, thick forest, light forest, bare ground and water body were identified and mapped. Analysis of Landsat images of 1984, 2000 and 2014 revealed that land use and land cover of the study area has changed 
over the study period. The greatest amount of change detected in the study area occurred in villages close to the Lagos-Ibadan Expressway and around settlements close to Lagos. Between 1984 and 2014, built up area gained 6423.38 hectares and increased from $8.51 \%$ to $59.31 \%$, also 8612.09 hectares of thick forest cover was degraded reducing its areal extent to $0.59 \%$ from $67.52 \%$. A post-classification change analysis from 1984 to 2014 reveals that thick and light forest types were mostly vulnerable to urban expansion.

Changes in land use and land cover of the area were found to be related to urban sprawl due to urbanization and population growth. Undoubtedly, many changes occurred between 1984 and 2000 when compared with those of 2014. Findings from this study have shown that the urban expansion largely from Lagos metropolis have indeed in the past thirty year being sprawling into the nearby rural communities due to the uncontrolled and unauthorized acquisition and conversion of lands. The changes have affected the morphology, population, economic and social activities the area in the past thirty years. Urban sprawl in the study area has resulted in the loss of productive agricultural land, open green spaces, loss of surface water bodies and depletion of ground water, solid waste disposal problems, water, air, and noise pollution. The information derived from the study can be useful in formulating effective land use management strategies and environmental policies and equip urban/environmental planners with relevant data that would enable them to promptly curtain the adverse effects.

\section{ACKNOWLEDGEMENT}

We appreciate the assistance of anonymous colleagues who helped to proofread the manuscript before submission. The Landsat satellite data used for this study were obtained from the official website of the Global Land Cover Facility (G L C F) (http://www:glcf.umiacs.umd.edu).

\section{REFERENCES}

Alberti, M., Booth, D. Hill, K. Marzluff, J. Avolio, C. Coburn, R. Coe, S. Donelly, R. and Spirandelli, D. 2000, The Impacts of
Urban Patterns on Ecosystem Dynamics. Seattle, WA: Univ. Washington.

Anderson, J. R., Hardy, E. E., Roach, J. T. and Witmer, R. E., 2001. A land use and land cover classification system for use with remote sensor data. U.S. Geological Survey Professional, Washington, DC: U.S. Geological Survey, Paper 964 pp 28.

Banai, R. and DePriest, T. 2014. Urban Sprawl: Definitions, Data, Methods of Measurement, and Environmental Consequences. The Journal of Sustainability Education(JSE) Vol 7 Dec 2014

Banzhaf, E. Grescho, V. and Kindler, A. 2009. Monitoring urban to peri urban development with integrated remote sensing and GIS information: A Leipzig, Germany case study. International Journal of Remote Sensing, 30(7):1675-1696

Bhatta, B. 2010. Analysis of Urban Growth and Sprawl from Remote Sensing Data. pp. 20-23 (Springer-Verlag: Heidelberg, Germany),

Belal, A.A. and Moghanm, F.S., 2011. Detecting urban growth using remote sensing and GIS techniques in Al Gharbiya governorate, Egypt. Egypt. J. Remote Sens. Space Sci, 14:73-79

Bhatta, B., Saraswatib, S. and Bandyopadhyay, D., 2010. Urban Sprawl Measurement from Remote Sensing Data, Applied Geography, 30(4):731-740.

Blaike, P. and Brookfield, H. 1987, Land Degradation and Society, 269 pp. (London: Rotuledge).

Borak, J. S., Lambin, E. F. and Strahler, A. H. 2000, The use of temporal metrics for landcover change detection at coarse spatial scales. International Journal of Remote Sensing, 21:1415-1432.

Briassoulis, H. 2000. Analysis of Land Use Change: Theoretical and Modelling Approaches. The web book of regional science, Scott Loveridge, (Ed.). Regional Research Institute, West Virginia University, USA. [Online]. Available: http://www.rri.wvu.edu/WebBook/Bria ssoullis/contents.htm [Accessed 
January18, 2015].

Bugliarello, G. 2003. Large urban concentrations: A new phenomenon. In Earth Science in the City: A Reader, G. Heiken, R. Fakundiny, and J. Sutter (Eds.). (New York: American Geophysical Union) pp.7-19.

Butt, A., Shabbir, R., Ahmad, S. S. and Aziz, N. 2015. Land use change mapping and analysis using Remote Sensing and GIS: A case study of Simly watershed, Islamabad, Pakistan. Egypt. J. Remote Sens. Space Sci. 18: 251-259.

Cheng, J. and Masser, I. 2003. Urban Growth Pattern Modelling: A Case Study of Wuhan City, PR China, Landscape and Urban Planning, 52:199 - 217.

Coppin, P., Jonckheere, I., Nackaerts, K., Muys, B., and Lambin, E., 2004. Digital change detection methods in ecosystem monitoring: a review. International Journal of Remote Sensing, 25(9):1565-1596.

Csatári, B., Farkas, J. Z. and Lennert, J. 2013. Land Use Changes in the Rural-Urban Fringe of Kecskemét after the Economic Transition. Journal of Settlements and Spatial Planning, 4(2): 153-159.

Defries, R. and Belward, A. S. 2000 Global and regional land cover characterization from satellite data; an introduction to the Special Issue. International Journal of Remote Sensing, 21(6\&7):1083-1092.

Eastman, J.R. 2012. IDRISI Selva Manual. Clark University: Worcester, MA, USA.

Fabiyi, O. 2006. Urban Land Use Change Analysis of a Traditional City from Remote Sensing Data: The Case of Ibadan Metropolitan Area, Nigeria. Department of Geography, University of Ibadan, Nigeria. Humanity and Social Sciences Journal 1(1): 42-64

Fohrer, N., Haverkamp, S., Eckhardt, K. and Frede, H.G. 2001. Hydrologic Response to Land Use Changes on the Watershed Scale. Hydrology, Oceans and Atmosphere, 26(7-8):577-582.

Ghebrezgabher, M.G., Yang, T., Yang, X., Wang, X. and Khan, M. 2016. Extracting and analyzing forest and woodland cover change in Eritrea based on Landsat data using supervised classification. Egypt. J. Remote Sens. Space Sci, 19:37-47

Hagner, O. and Reese, H. 2007. A method for calibrated maximum likelihood classification of forest types. Remote Sensing of Environment, 110: 438-444.

Ifatimehin, O. O. and Ufuah, M. E. 2006. An Analysis of Urban Expansion and Lost of Vegetation Cover in Lokoja, Using GIS Techniques. Zaria Geographer: Journal of Environmental Studies and Human Development, 17(1):28-36.

Iqbal, M.F. and Khan, I.A. 2014. Spatiotemporal land use land cover change analysis and erosion risk mapping of Azad Jammu and Kashmir, Pakistan. Egypt. J. Remote Sens. Space Sci. 17:209-229.

Jensen, J.R. 2000. Remote Sensing of Environment: An Earth Resource Perspective. (Englewood Cliff: Prentice Hall).

Kemper, G., Altan, O., Pátíková, A. and Lavalle, C. 2001. Monitoring Landuse change of the city of greater Istanbul, (Forth international Symposium "TurkishGerman Joint Geodetic Days" Vol 2, Berlin

Kumar, M. and Tripathi, D. K. 2014. Spatial Monitoring of Urban Growth of Nagpur City(India) Using Geospatial Techniques. Journal of Settlements and Spatial Planning, 5(2):91-98.

Lillesand, T.M. and Kiefer, R.W. 2000. Remote Sensing and Image Interpretation. John Wiley.

Lu, D., Mausel, P., Brondízio, E. and Moran, E. 2004. Change detection techniques. International Journal of Remote Sensing, 25(12):2365-2401

Mahesh, K. J., Garg, P.K. and Deepak, Khare. 2008. Monitoring and modeling of urban sprawl using remote sensing and GIS techniques. International Journal of Applied Earth Observation and Geoinformatics, 1:10-26

Marsh, G. P. 2013; Man and Nature, or the Earth as Modified by Human Action. Lowenlhat; D. (Ed.) 218 pp. The classic.us 
Masek, J. G. And Lindsay, F.E. 1996. Landsat observations. International Journal of Remote Sensing, 21(18): 3473-3486.

Masek, J.G., Vermote, E.F., Saleous, N.E., Wolfe, R., Hall, F.G., Huemmrich, F., Gao, F., Kutler, J. and Lim, T.K. 2006. A Landsat surface reflectance data set for North America, 1990-2000. IEEE Transactions on Geoscience Remote Sensing and Letters 3:69-72.

Masoumi, H.E. and Roque, D., 2015, Evaluation of Urban Sprawl Speed and Intensity Based on International Urbanization. Example from a Mexican City. Journal of Settlements and Spatial Planning, 6(1):27-35

McGranahan, G. and Tacoli, C. 2006. Rural-urban migration in China: policy options for economic growth, environmental sustainability and equity. In: Human Settlements Working Paper Series Rural-Urban Interactions and Livelihood Strategies. IIED 12, London.

Melendez-Pastor, I., Hernández, E.I., NavarroPedreño, J. and Gómez, I. 2014. Socioeconomic factors influencing land cover changes in rural areas: The case of the Sierra de Albarracín (Spain). Applied Geography, 52:34-45

Meyer, W. B. and Turner, B.L. II (Eds.), 1994, Changes in Land Use and Land Cover. $A$ Global Perspective. 713 pp. (Cambridge: Cambridge University Press).

Miller, H.M., Sexton N.R., Koontz, L., Loomis, J., Koontz, S.R. and Hermans, C. 2011. The Users, Uses, and Value of Landsat and Other Moderate-Resolution Satellite Imagery in the United States-Executive Report. (U.S. Geological Survey OpenFile Report 2011-1031, U.S. Geological Survey: Reston, VA, USA).

Mozumder, C. and Tripathi, N.K. 2014. Geospatial scenario based modelling of urban and agricultural intrusions in Ramsar wetland Deepor Beel in Northeast India using a multi-layer perception neural network. Int. J. Appl. Earth Observ. Geoinf. 32: 92-104.

Mussie, O. 2011, Bias on land cover change estimates due to misregulation. International Journal of Remote Sensing 21:3553-3560

Nagarajan, N. and Poongothai, S. 2011. Identification of Land use and Land cover Changes using Remote Sensing and GIS. IACSIT International Journal of Engineering and Technology, 3(5):570576

Olawole, M.O., Msimanga, L., Adegboyega, S.A. and Adesina, F.A. 2011. Monitoring and Assessing Urban Encroachment into Agricultural Land - A Remote Sensing and GIS Based Study of Harare, Zimbabwe. Ife Journal of Science, 13(1):149-160

Ozturk, D. 2015, Urban Growth Simulation of Atakum (Samsun, Turkey) Using Cellular Automata-Markov Chain and Multi-Layer Perception-Markov Chain Models. Remote Sens. 7:5918-5950. Doi: $10.3390 /$ rs70505918

Pidwirny, M. 2011. Koppen climate classification system. [Online].Available: http://www.eoearth.org/view/article/16 2222 [Accessed April 27,2017].

Rahman, A., Aggarwal, S. P., Netzband, M. and Fazal, S. 2011. Monitoring Urban Sprawl Using Remote Sensing and GIS Techniques of a Fast Growing Urban Centre, India. IEEE Journal of Selected Topics in Applied Earth Observations and Remote Sensing, 4(1):56-64

Rosa, E.A., York, R. and Dietz, T. 2004. Tracking the Anthropogenic Drivers of Ecological Impacts. Ambio: A Journal of the Human Environment, 33(8):509-512.

Shalaby, A. and Gad, A., 2010. Urban Sprawl Impact Assessment on the Fertile Agricultural Land of Egypt Using Remote Sensing and Digital Soil Database, Case study: Qalubi Governorate. US-Egypt Workshop on Space Technology and Geo-information for Sustainable Development, Cairo, Egypt 14-17 June 2010

Shalaby, A. and Tateishi, R., 2007. Remote sensing and GIS for mapping and monitoring land-cover and land-use changes in the Northwestern coastal zone of Egypt. Applied Geography. 27:28-41. 
Siciliano, G. 2013. The social and environmental implications of urbanization strategies and domestic land grabbing in China: The case of Chongming Island. LDPI Working Paper 14. The Land Deal Politics Initiative. [Online].Available: www.iss.nl/Idpi [Accessed June 9, 2018].

Stanley, J. 2009. FMO Research guide: development induced displacement and resettlement, Available at: http://repository.forcedmigration.org/s how_metadata.jsp?pid=fmo:5135

[Accessed July 13, 2015].

Stow, D. A. and Chen, D. M. 2000. Sensitivity of multitemporal NOAA AVHRR data of an urbanizing region to land use/ landcover changes and misregistration. Remote Sensing of Environment, 80:297-307.

Sudhira, H. S., Ramachandra, T.V. and Jagadish, K.S. 2004. Urban Sprawl: Metrics, Dynamics and Modeling Using GIS. International Journal of Applied Earth Observation and Geoinformation, 5(1):29-39.

Tan, K., Lim, H., Matjafri, M. and Abdulla, K. 2010, Landsat data to evaluate urban expansion and determine land use/land cover changes in Penang Island, Malaysia. Environmental Earth Science, 60:15091521.

Tang, Z., Engel, B.A., Pijanowski, B.C. and Lim, K. J. 2005. Forecasting Land Use Change and its Environmental Impact at a Watershed Scale. Journal of Environmental Management, 76:35-45.

Tempfli, K., Kerle, N., Huurneman, G. C. and Janssen. L.L.F. (Eds.) 2002. Principles of Remote Sensing. ITC Educational Textbooks Series; 2, Second Ed.

Tewolde, M.G. and Cabral, P., 2011. Urban sprawl analysis and modeling in Asmara, Eritrea. Remote Sens. 3:2148-2165.

Tian, G., Liu, J., Xie, Y., Yang, Z., Zhuang, D. and Niu, Z. 2005. Analysis of spatio-temporal dynamic pattern and driving forces of urban land in China in 1990s using TM images and GIS. Cities, 22(6): 400-410

Tiwari, M.K., Saxena, A. and Katare, V. 2012. Mapping and evaluation of urban sprawl using an integrated approach of Remote Sensing and GIS Technique (Review). International Journal of Advanced Technology \& Engineering Research (IJATER)2(1):21-29

Tu, J., Xia, Z. and Clarke, K. 2007. Impact of urban sprawl on water quality in eastern Massachusetts, USA. Environmental Management, 40:183-200.

Weng, Q. 2010. Remote Sensing and GIS Integration; Theories, Methods, and Applications, (New York: McGraw-Hill).

Weng, Q. 2012. Remote sensing of impervious surfaces in the urban areas: Requirements, methods, and trends. Remote Sensing of Environment, 117:34-49.

Wickham, J.D., O'Neill, R.V. and Jones, K.B. 2000. A geography of ecosystem vulnerability. Landscape Ecology, 15:495-504

World Bank. 2015. Leveraging Urbanization in South Asia: Managing Spatial Transformation for Prosperity and Livability, Conference Edition. International Bank for Reconstruction and Development / The World Bank. Doi: 10.1596/978-1-4648- 0662 - 9 . A v a i 1 a b 1 e a $t$ : https://openknowledge.worldbank.org/ [Accessed April 27, 2016].

Xiao, J., Shen, Y., Ge, J., Tateishi, R., Tang, C., Liang, Y. and Huang, Z. 2006. Evaluating urban expansion and land use change in Shijiazhuang, China, by using GIS and remote sensing. Landscape and Urban Planning, 75(1-2):69-80.

Zang, S., Wu, C., Liu, H. and Na, X., 2011. Impact of urbanization on natural ecosystem service values: A comparative study. Environmental Monitoring and Assessment. 179:575-588. 